Article

\title{
Knowledge Integration in the Politics and Policy of Rapid Transitions to Net Zero Carbon: A Typology and Mapping Method for Climate Actors in the UK
}

\author{
Steven R. Smith ${ }^{1, *(D)}$ and Ian Christie ${ }^{1,2}$ \\ 1 Centre for Environment and Sustainability (CES), University of Surrey, Surrey GU2 7XH, UK; \\ i.christie@surrey.ac.uk \\ 2 Centre for the Understanding of Sustainable Prosperity (CUSP), University of Surrey, Surrey GU2 7XH, UK \\ * Correspondence: steven.r.smith@surrey.ac.uk
}

Citation: Smith, S.R.; Christie, I Knowledge Integration in the Politics and Policy of Rapid Transitions to Net Zero Carbon: A Typology and Mapping Method for Climate Actors in the UK. Sustainability 2021, 13, 662 https://doi.org/10.3390/su13020662

Received: 31 October 2020 Accepted: 7 January 2021

Published: 12 January 2021

Publisher's Note: MDPI stays neutral with regard to jurisdictional clai$\mathrm{ms}$ in published maps and institutional affiliations.

Copyright: (C) 2021 by the authors. Licensee MDPI, Basel, Switzerland. This article is an open access article distributed under the terms and conditions of the Creative Commons Attribution (CC BY) license (https:// creativecommons.org/licenses/by/ $4.0 /)$.

\begin{abstract}
The types of political and policy knowledge required to guide rapid transition to low-carbon economies remain largely disconnected in the fields of political science, psychology, and sociology. The composition and key features of the main actors involved, and their relationships have also not been systematically described. This paper attempts to address these knowledge gaps by proposing a new, integrative typology of actors involved in climate change mitigation policy in the United Kingdom (UK) and a method for mapping these actors and selecting their typological descriptors onto a 2D space. The mapping method enables stakeholders to visualise and evaluate the strength of support for the UK government's net-zero-by-2050 "green growth" strategy and the tensions, challenges, and strategic opportunities potentially facing more radical alternatives. The methodology could be replicated for climate actors in other countries and, in principle, for any geographical scale or level of governance.
\end{abstract}

Keywords: climate; actors; mitigation; politics; policy; rapid; transition; transformation; typology; mapping

\section{Introduction}

Climate scientists have warned that, in order to avoid potentially catastrophic consequences for humanity and planetary ecosystems, rapid decarbonisation of the global economy is necessary and urgent $[1,2]$. The efforts of the international community to date have resulted in the 2015 Paris Agreement [3] - a system of non-binding Intended Nationally Determined Contributions (INDCs) - and an ambition to limit global warming to $1.5^{\circ} \mathrm{C}$ above the preindustrial average and to achieve net zero carbon global emissions by mid-century. When added up, current INDCs are forecasted to lead to between $+3.2^{\circ} \mathrm{C}$ and $+3.7^{\circ} \mathrm{C}$ of warming, and no G20 nation is currently on track to meeting even these $[2,4,5]$.

Much research to address this "grand challenge" has been overwhelmingly sociotechnical in focus [6]. There is much less research and knowledge concerning the question of how political will and social resources can be generated to meet the urgency of climate disruption. Even where such knowledge exists, it tends to remain within the disciplinary boundaries of sociological studies of protests and social movements; business and organisation management; psychosocial dimensions of human values and motivations; and governance, law, and the policy process. As Gillion [7] (p.10) noted, "Real world events do not have the same disciplinary constraints found in academia." Climate change politics over the last few years has amply demonstrated the complex, rapidly evolving, and multidimensional nature of real-world events.

Within this context, this paper seeks to identify a broad range of political and policy actors influencing the transition to net zero carbon in the UK, together with a list of key actor descriptors as informed by social science research [8-10]. The "landscape" of 
actors is complex, crowded, and changeable, and we see benefits for policy and advocacy organisations in having a visualisation tool and categorisation of the scene. We develop a novel typology for categorising the elements in this landscape and use a selection of them-actor type, actor sector, net-zero policy ambition, policy discourse, and relative policy influence-to map the actors onto a $2 \mathrm{D}$ space. The mapping format is intended to help stakeholders visualise the political landscape of greenhouse gas (GHG) mitigation in the UK and to evaluate the relative strengths, challenges, tensions, strategic opportunities, and alignments available for the expanding "ecosystem" of non-state actors.

Some experts have argued that a transition genuinely based on sustainability, equity, and capability [3] would oblige richer countries, including the UK, to develop net zero carbon economies well in advance of the global mid-century target [11,12]. It has also been argued that such a rapid transition, for example, one that achieves net zero carbon in the 2030s, would incur costs in excess of economic growth-thereby violating an imperative that is deeply embedded in the institutions, values, and worldviews of almost all business and governance actors. The dominant transition strategy therefore calls for a more managed, incremental, "ecomodernist" approach that relies on "green growth" via innovation in technologies rather than on radical shifts in consumption and values [13-18]. Our proposed typology and mapping framework may be particularly beneficial to more radical actors in their struggle to identify, persuade, and build common causes with a small but diverse alliance of advocates for rapid transition to net zero.

The remainder of this Introduction reviews existing typologies and maps of actors influencing UK climate change mitigation politics and policy. Section 2 describes the methodology used to create a novel typology and map. Section 3 presents the resulting typology, with a sample organigram of current UK state actors and a map of non-state actors. Section 4 discusses how the map can be used to generate useful perspectives, insights, strategies, and scenarios for effective alliance-building within the politics/policy ecosystem. Section 5 offers conclusions and recommendations.

\subsection{Existing Typologies of Environmental Policy Actors}

Previous typologies of environmental organisations have categorised actors in terms of their geographical scale, policy discourse, organisation type, economic sector, and method of operation. The following are examples:

(a) Scale: Barbrook-Johnson [19] categorised UK organisations involved in public-private partnerships in the food-energy-water-environment nexus by their geographical scale of operation at the catchment, county, regional, devolved nation, UK, or international levels;

(b) Policy discourse: the categorisation of policy discourses in climate change politics helps to understand how issues are framed and how policy discourses relate to each other in terms of aligning/competing groups [20-22]. Hess [23] argued that a focus on language and discourse coalitions, rather than on shared core beliefs or identities [24,25], offered greater flexibility in understanding the dynamics of coalitions, for which the goals and compositions may change in response to persuasive counter-framing, new information, events, changes in administration, membership, and institutional form [26] (This point is reiterated below when considering the advantages and disadvantages of various mapping methodologies). Boehnert [27] categorised UK, US, and Canadian actors via five policy discourses: climate science, climate justice, ecological modernisation, neoliberalism, and climate contrarianism.

(c) Organisation type: Costoya [28] proposed a four-part typology of civil society actors based on their organisation, vision of civil society, and logic of social action: (1) NonGovernmental Organisations (NGOs), (2) social movements, (3) networks, and (4) plateaus. Networks and plateaus were viewed as information-age correlates of the more traditional NGOs and social movements. This typology is summarised in Table 1, column A. Boehnert [27] differentiated actors into 12 types: governments, intergovernmental organisations, science research institutions, media organisations, non-governmental organisations/charities, associations and societies, climate research 
institutes and think tanks, websites/blogs, contrarian blogs, contrarian organisations, individuals, and corporations.

(d) Sector: various typologies arrange stakeholders into the sector of the economy in which they operate, as summarised in Table 1, column B. The following are examples:

- The UK's Committee on Climate Change (CCC) publishes "indicator frameworks" for seven sectors of the economy-power, buildings, industry, transport, agriculture and land-use, land-use change and forestry, waste, and F-gases [29].

- Scoones et al. [30] discussed the importance of non-state actors in business, finance, academia, grassroots, and social movements. According to Sovacool and Geels [31], actors also include households, businesses, policymakers, social movements, scientists, journalists, investors, and special interest groups.

- Oxfam International's [32] guidelines for analysing social and political change processes list social movements, political parties, political and business elites, the military, police, inspirational leaders, and faith leaders as agents of change.

- Climate Assembly UK [33] included an advisory panel representing academic research, think tanks, business associations, environmental organisations, citizen organisations, and trade unions.

- Boehnert [27] mapped various types of media organisations in three categories: journals, newspapers, and television broadcasters; websites; and contrarian blogs.

(e) Method of operation: There is an expanding range of methods used to engage with civil society and government [34]. Table 1, column C lists these methods, including recent innovations.

Combining elements of scale (a) and organisation type (c), Rao et al. [35] developed a $2 \times 2$ framework of social and political change processes in which scale varies from individual to systemic ( $y$-axis) and institutions/organisations vary from informal to formal $(x$-axis). This typology (Figure 1$)$ is helpful in illustrating the need for more integrated, cross-disciplinary thinking about how change happens [7,32].

Table 1. Consolidating existing typologies of environmental policy actors.

\begin{tabular}{|c|c|c|}
\hline A & B & $\mathrm{C}$ \\
\hline $\begin{array}{l}\text { Non-Governmental Organisation (NGO) } \\
\text { (e.g., WWF, Friends of the Earth } \\
\text { Business associations } \\
\text { Trade Unions } \\
\text { Think Tanks) } \\
\text { Social Movement } \\
\text { (e.g., 350.org, School Strike } 4 \text { Climate, } \\
\text { Extinction Rebellion) } \\
\text { Network } \\
\text { (e.g., Climate Action Network; } \\
\text { Global Climate Forum } \\
\text { Transition Towns) } \\
\text { Plateau } \\
\text { (e.g., World Social Forum) }\end{array}$ & $\begin{array}{l}\text { Academia } \\
\text { The Arts } \\
\text { Business } \\
\text { Citizen NVDA } \\
\text { Energy Generation } \\
\text { Farming } \\
\text { Finance } \\
\text { Health } \\
\text { Law/Litigation } \\
\text { Local Politics } \\
\text { Media } \\
\text { National Politics } \\
\text { Prefigurative Movements } \\
\text { Religion } \\
\text { Trade Unions } \\
\text { Transport }\end{array}$ & $\begin{array}{l}\text { Method/Modus Operandi } \\
{[34,36,37]} \\
\text { Traditional Methods: } \\
\text { Demonstrate } \\
\text { Strike } \\
\text { Occupy public/private space } \\
\text { Donate/subscribe } \\
\text { Petition } \\
\text { Lobby } \\
\text { Print } \\
\text { Public Meeting } \\
\text { Boycott } \\
\text { Exhibition } \\
\text { Theatrical Performance } \\
\text { Artwork } \\
\text { Civil Disobedience } \\
\text { Policy Advocacy } \\
\text { Disinformation/astroturfing } \\
\\
\text { Recent Methods: } \\
\text { Litigate (as Plaintiff) } \\
\text { Strike from School } \\
\text { Internet-based Calls to Action } \\
\text { Divest/Reinvest } \\
\text { Digital Media Influencing } \\
\text { Prefigurative Politics }\end{array}$ \\
\hline
\end{tabular}




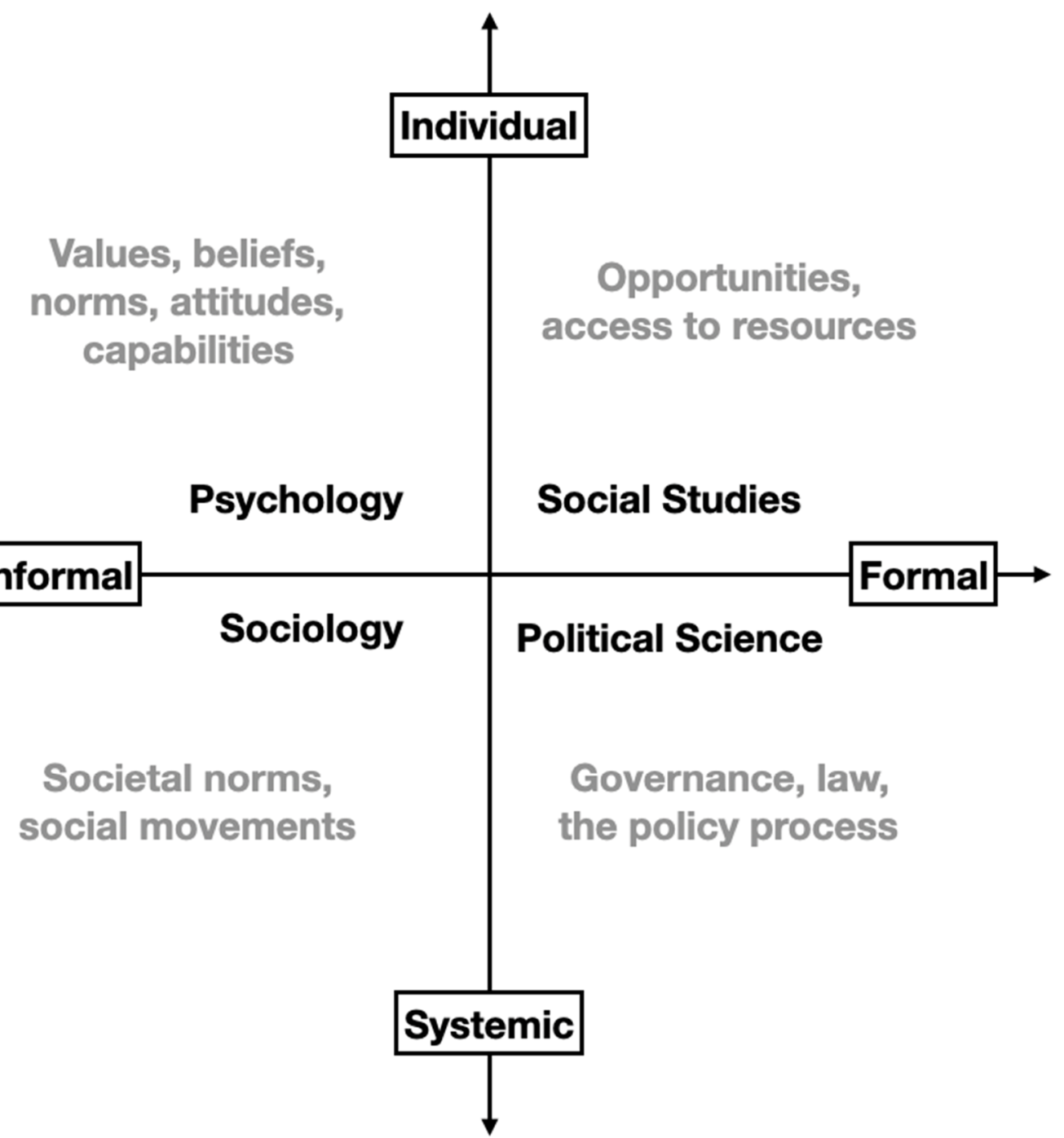

Figure 1. Framework of social and political change processes (adapted from [32] (p. 6).

\subsection{Existing Organigrams and Maps}

Several kinds of organigrams and maps have been created to illustrate climate policy networks. A policy network is "a cluster ... of organisations connected ... by resource dependencies and distinguished from other clusters by breaks in the structure of resource dependencies" [38] (p. 4).

An organigram (Figure 2) of the UK climate policy network was created by the Tyndall Centre for Climate Change Research [38]. It included government agencies and departments and acknowledged that business representatives and NGOs have an input to the policy process. 


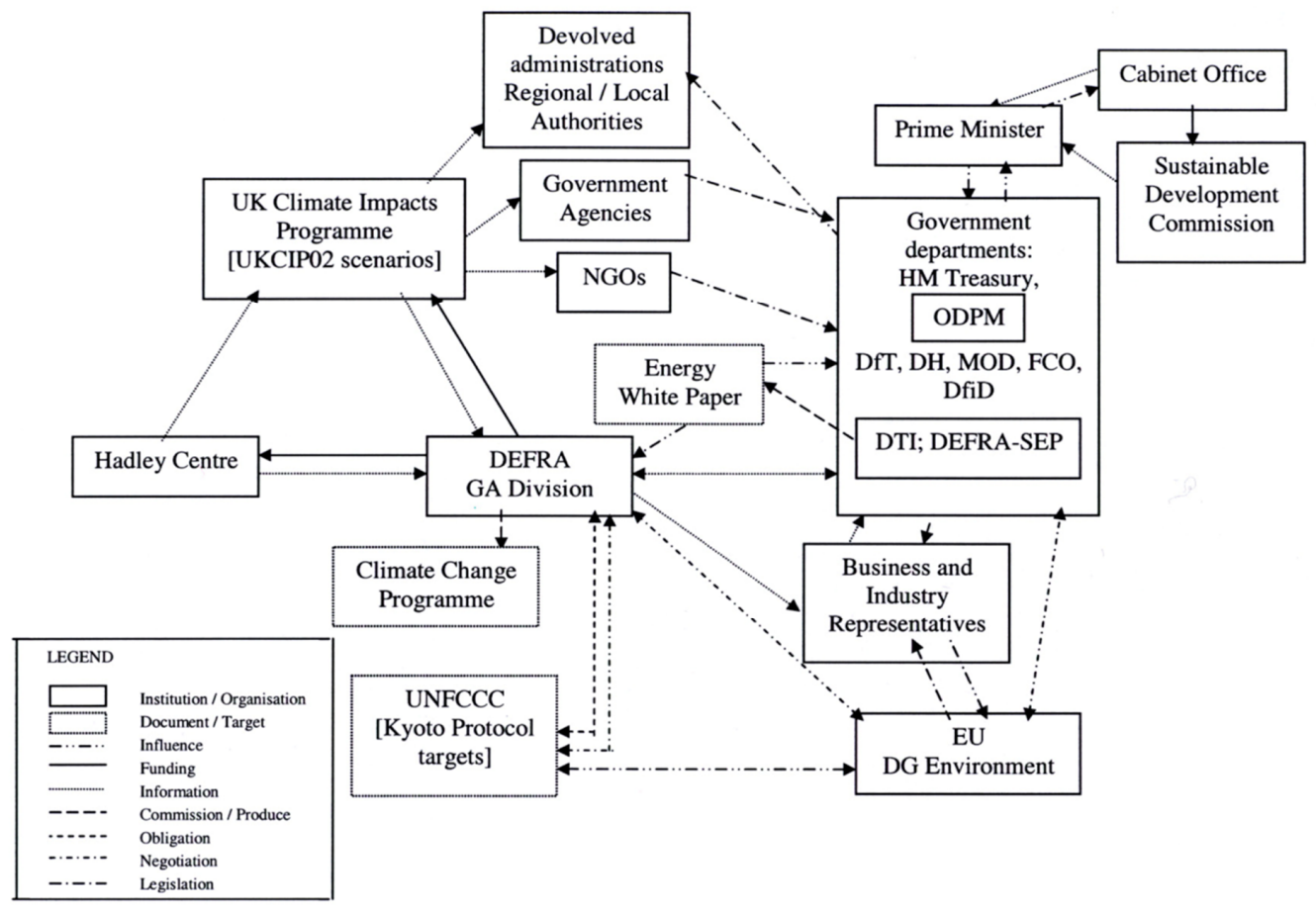

Figure 2. Policy network for climate change in the UK [38] (reproduced with permission).

More recently, Willis et al. [39] created maps of current and proposed actors in UK energy governance, including detailed breakdowns of local authority and market dimensions of energy production and distribution networks (Figure 3).

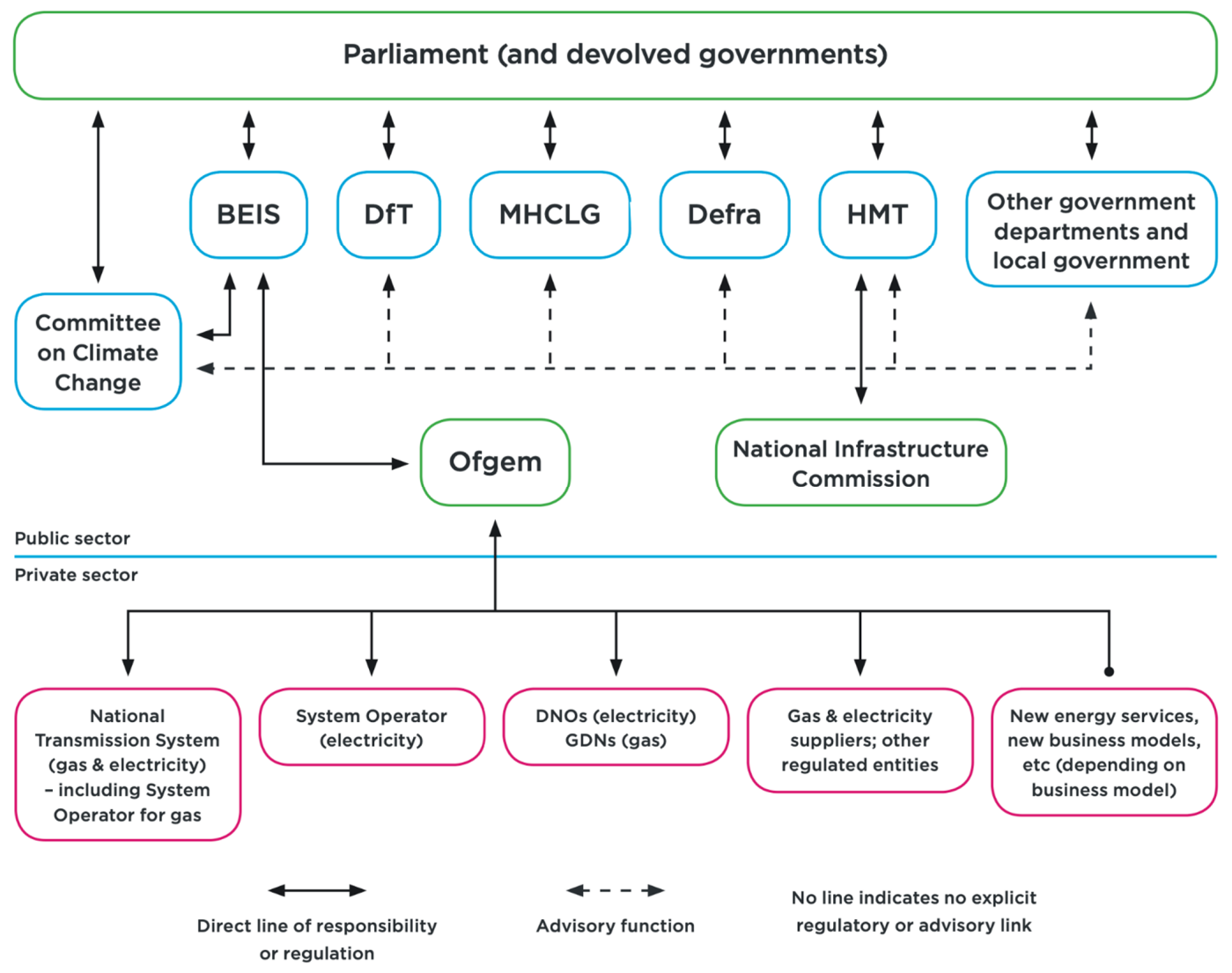

Figure 3. UK Energy Governance: current institutions and responsibilities [39] (reproduced with permission). 
Organigrams such as these provide useful overviews of the distribution of formal roles in national governance frameworks. However, they offer little information about subor supra-national influences or the wider political opportunity structures and informal inputs of non-state actors in business and civil society [40-43].

Barbrook-Johnson [19] developed several methods for mapping public-private partnerships in the UK food-energy-water-environment nexus. One infographic (Figure 4a) differentiates between individual and "umbrella" (multiple) partnerships and situates them on $x / y$ axes according to their environmental domain ( $x$ axis) and geographical scale ( $y$ axis).



(a)

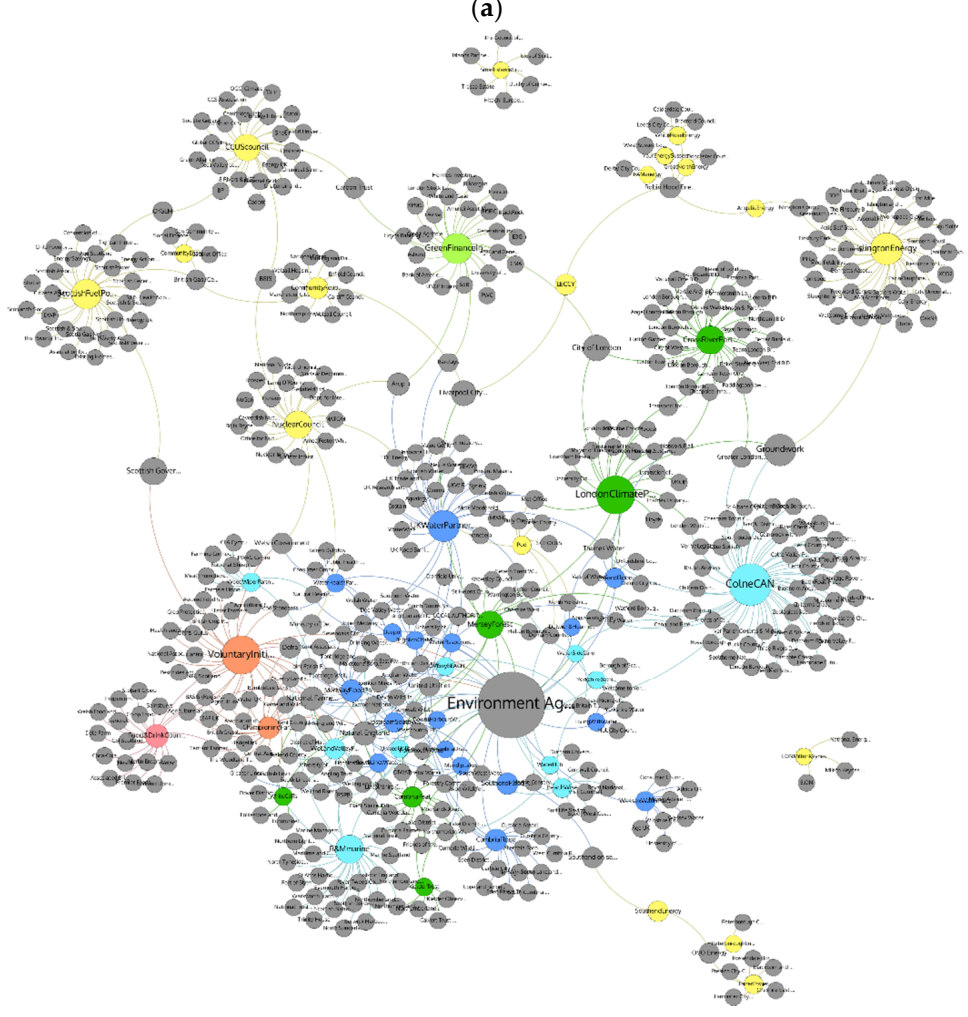

(b)

Figure 4. (a) Public-private partnerships by domain and scale [19] (reproduced with permission) and (b) a network diagram of public-private partnerships [19] (reproduced with permission). 
A second method (Figure $4 \mathrm{~b}$ ) created a network diagram of all 55 partnerships (coloured according to their domain) linked to 462 individual organisations (in grey: 140 public sector, 185 private sector, and 137 NGOs), laid out using algorithms that minimise crossed lines and situate larger partnerships more centrally.

Barbrook-Johnson's [19] methods provide much greater detail of the non-state actors involved in these public policy issues, their connections, and their geographical reach. However, neither method offers any indication of actors' policy positions in terms of discourses, coalitions, and alignments or their relative "power" in terms of political influence [44-46].

One attempt to visualise discourses and influence was Boehnert's [27] rich illustration of UK, American, and Canadian actors in climate change communications (Figure 5). Actors were presented as individual circles and positioned and coloured in relation to five policy discourses: climate science, climate justice, ecological modernisation, neoliberalism, and climate contrarianism. The diameter of each actor's circle was sized according to "relative influence", which was determined by various combinations of metrics (e.g., population, revenue, Alexa ranking, twitter following, membership, and readership) depending on the type of actor (e.g., government, media organisation, corporation, and think tank). Since there is no objective measure of "influence" or a unifying unit of measurement across organisational types, Boehnert [27] relied on a degree of subjective value judgement based on experience.

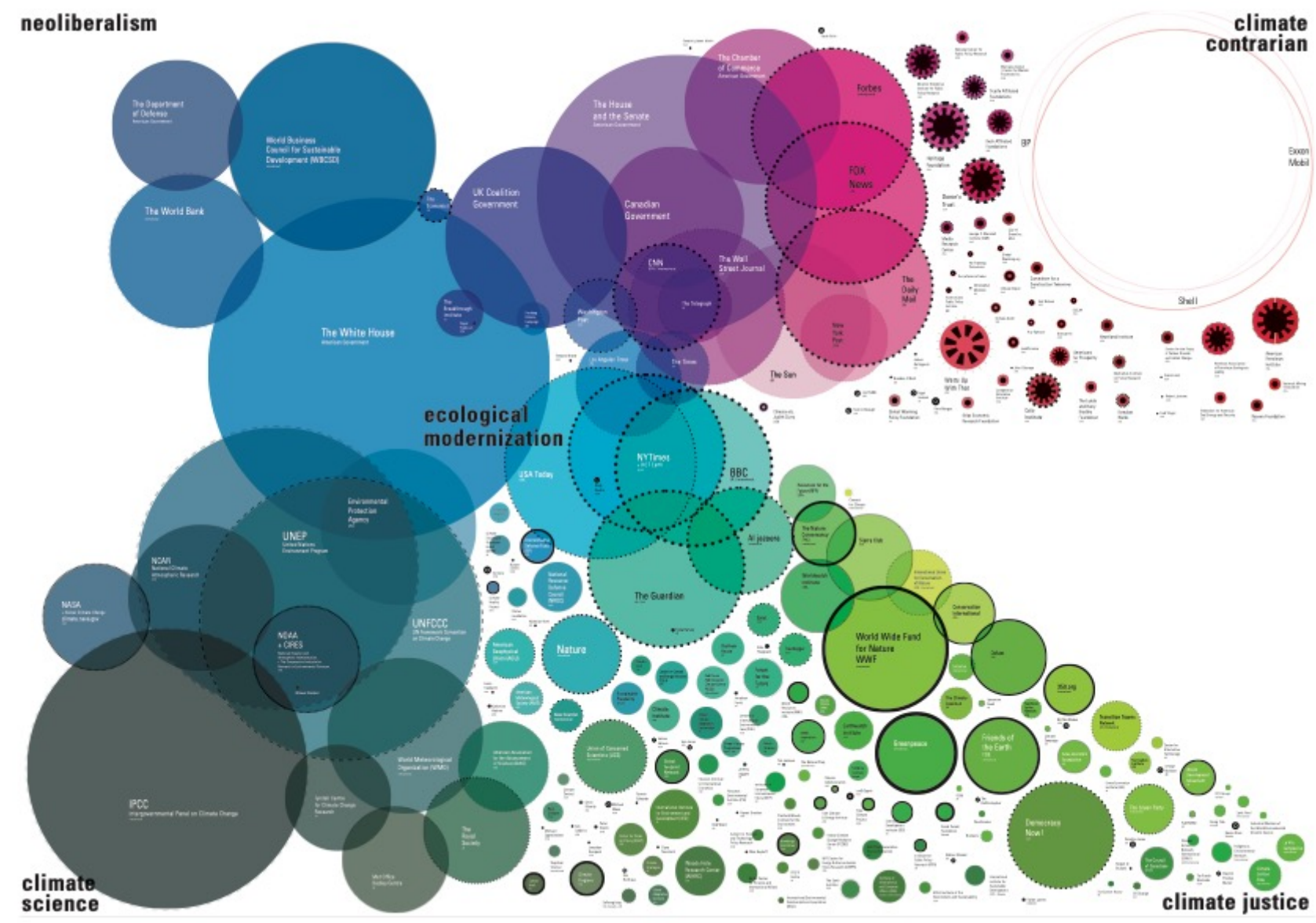

Figure 5. US, UK, and Canadian actors in climate communication [27] (Reproduced with permission).

Boehnert's [27] mapping method is a useful way to visualise some of the underlying ideologies and rhetorical positions of actors engaged in climate change politics and provides some indication of likely alliances, opponents, and their relative influence. However, the categorisations themselves are subject to challenge, interpretation, context, and change. For example, 
many actors labelled "neoliberal" and "ecomodernist" may also claim to be informed by "science" and "justice". Some actors, such as those specialising in deliberative/participatory approaches to collective decision-making, prefer to remain ideologically neutral. Furthermore, as in Barbrook-Johnson's [19] network diagram (Figure 4b), Boehnert's [27] Figure 5 is a "free-floating" infographic, unanchored to any geographical scale, governance framework, or specific policy goal.

An attempt to illustrate a combination of influence, alignment, and strategy of climate actors with regard to a specific policy was made by Oxfam International [32] (Figure 6). This was a $2 \times 2$ "power mapping" framework that was able to provide a strategic overview of countries' policy positions and coalitions in the run-up to the 2015 Paris climate negotiations. Countries and coalitions of countries were colour-coded into "core/deal-makers", "deal-blockers", "swing states", and "climate champions", and positioned along the $x$-axis according to their level of influence (from less powerful to more powerful) and along the $y$-axis according to their level of support for $\mathrm{a}+2{ }^{\circ} \mathrm{C}$ climate target.



Figure 6. A Power Mapping Framework [32] (reproduced with permission).

In what follows, we set out an innovative methodology aiming to integrate and build on these previous approaches to categorise and map the landscape of climate actors. The focus is on actors engaged in a specific policy goal: the UK's net zero carbon target.

\section{Materials and Methods}

\subsection{Data Scope}

Political and policy actors in the UK transition to a low-carbon economy are influenced by a range of other actors, institutions, and events at the international scale [47] as well as by the policies and other initiatives of devolved nations, regions, cities, and local government [48]. Our typology and actor-mapping method may be applicable for all scales. However, the sample organigram and map presented in the results section largely capture the national scale, with an overview of international and subnational actors. Individual companies are not included in this map but are instead represented by the relevant networks, institutes, and alliances. Both the typology and maps include actors actively engaged in the politics and policy advocacy of greenhouse gas (GHG) mitigation rather than all stakeholders (i.e., everyone impacted by policy); they do not include those engaged in climate-related 
adaptation. Also omitted are organisations whose primary purpose is to provide funds to support climate-related projects.

\subsection{Methods}

Data collection for the typology and mapping tasks was part of a wider research project, which we will document in forthcoming publications, that involved 47 face-to-face interviews with a cross section of campaigners, politicians, business leaders, scholars, and other experts in the field of sustainable transitions research. Other primary data were gathered from public presentations, webinars, workshops, televised debates, and email enquiries to relevant institutions. Secondary data included published reports, webpages, articles, select committee hearings, and conference proceedings. Material used to create categories of "policy discourse" was transcribed and subjected to qualitative thematic analysis.

\subsection{Method for Typology Design}

Combinations of existing typological descriptors formed the basis of the new typology, with additional elements. The typology and maps were structured as follows (notes in parentheses explain how the typology is reflected in the sample organigram and map, where applicable):

1. Name (actor label): name of the organisation;

2. Scale (y-axis): the scales used in this typology are (1) district, (2) region/county, (3) devolved nation, (4) United Kingdom (includes international organisations with a UK office), and (5) international (without a UK office). This scaling corresponds to the administrative areas derived from the Nomenclature of Units for Territorial Statistics [49] (Table 2).

3. Net-zero ambition ( $x$-axis): the wider research project that generated this study is focused on the UK net zero carbon policy. Data collected for this paper was similarly restricted to actors' net-zero policy preferences for the UK as a whole. It is worth noting that some scholars and campaigners have criticised the entire "netzero" approach, arguing instead for more stringent "absolute zero" emissions targets. Others advocate separate accounting practices for positive and negative emissions. It is also worth noting that net-zero GHG targets are not strictly comparable using only the stated year, since long-term cumulative GHG budgets depend on other factors, including the mitigation pathway (convex, concave, and linear pathways imply different overall GHG emissions); the emissions "scope" (usually referred to as scopes 1,2, and 3), which specifies the boundary between what is counted and what is omitted; and the reliance on international offsetting and other negative emissions schemes. In addition, some actors specify their UK net-zero policy preference over a range of years, such as "well before 2050" or "by the late 2030s". The net-zero targets should therefore be viewed as broad approximations of actors' degrees of urgency/ambition, providing useful insights in terms of alignments and tensions within and between economic sectors, GHG mitigation sectors, policy discourses, and other category data. For these reasons, net-zero ambition is designated in ranges from 2025-2030, 2031-2035, 2036-2040, 2041-2045, 2046-2055, and >2055;

4. Policy discourse (actor colour): primary data collected from forty-seven expert interviewees, conferences, workshops, and other transcribed sources, together with secondary material from organisation webpages, reports, journals, and other media, were subjected to thematic analysis [50]. Key themes were developed into an analytical hierarchy-iterating between data management, descriptive accounts, and explanatory accounts-designed to build a conceptual "scaffolding" of broader meanings [51]. The initial reading of the data was literal, and the initial labelling and thematic framework was descriptive or semantic [52]. Thematic analysis of the policy discourses identified in this study (to be detailed in a forthcoming paper) resulted in the following five categories, each of which were allocated a colour in the non-state actors map: 
- Revolution (red): this represents actors proposing (quasi-) revolutionary, as opposed to reformist, solutions to the climate crisis. According to these actors, the current capital and elite-controlled system of government is incapable of adequate reform, necessitating system overthrow;

- Participation (yellow): this discourse prioritises democratic participation and collective decisions on targets, pathways, and solutions in the transition to a low-carbon society. "Participation" actors are therefore not assigned to "a priori" net-zero targets;

- Limits (green): this discourse gives primacy to the biophysical capacities and social foundations of a sustainable future. This is a post-growth policy discourse. It points out that infinite economic growth on a finite planet is not possible; moreover, beyond a threshold level of income, it bears little relation to what people really value;

- Growth (blue): this is the nationally and globally dominant policy discourse. It argues that the transition to a low-carbon economy is either compatible with or requires continued GDP growth;

- Delay (purple): this discourse dismisses decarbonisation as a policy priority. Proponents tend to be connected to the fossil fuel industry and/or to an economic libertarian ideology that opposes government intervention.

5. Relative influence (non-state actor size): six units of measurement were used in different combinations to calculate non-state actor influence on policy, depending on the social movement or NGO sector and data availability: Alexa Rank 90 Day Trend (https: / www.alexa.com/siteinfo); Twitter following (https:/ / twitter.com); revenue (https: / / www.influencewatch.org; https: / / beta.charitycommission.gov.uk; https:/ / suite.endole.co.uk); number of MPs (https:/ / members.parliament.uk); readership (https: / / www.newsworks.org.uk; organisation webpages); and think-tank ranking [53]. As in Boehnert [27], a degree of subjective judgement was used but was further refined by commentary from an informal expert review panel (see Acknowledgements). It was not possible to compare actors across sectors. All calculations were standardised as a percentage of the highest score (or in the case of Alexa Rank, the lowest score) of actors within each sector. The average total score for each actor was used as the final object diameter (from 1-100 units) for fourteen NGO sectors, social movements, and individuals, totalling sixteen non-state sectors. Each of these populates a single row in the whole UK section of the map of non-state actors. State actors were not sized by "relative influence".

6. Policy insider/outsider: Newell [54] and Piggot [55] differentiated "insider" individuals and organisations, who typically provide advice and/or research to government for policy development, from "outsider" individuals and organisations, who tend to be excluded from the policy process. Insider/outsider status is a strong indicator of an organisation's methods (item 9): outsiders are more likely to use protest tactics whereas insiders tend to use lobbying, advocacy, and research. It is also an indicator of policy radicalness: insiders are less inclined to push for more radical policies [55]. Insider/outsider status is closely associated with but not identical to relative influence (item 5). The most interesting individuals and organisations for those committed to more rapid decarbonisation are the exceptional "radical insiders": those with privileged access who push for more radical policy [56]. Unsurprisingly, insiders tend to influence policy more than outsiders, but there are contexts in which outsiders can rapidly affect change, a recent example being the Black Lives Matter movement $[57,58]$. Where coalitions formally invite a broad range of insiders and outsiders to achieve a common goal, for example, the IPPR's Environmental Justice Commission, the insider/outsider distinction may become otiose. The existence of a diverse "ecology" of insider and outsider NGOs and social movements may also provide strategic benefits: for example, the outsider tactics of Greenpeace and Extinction Rebellion may make it impossible to for them to build direct relationships with 
powerful incumbents in the government, business, or finance. However, if accompanied by sufficient media attention and public sympathy/outrage, they may force these incumbents to raise their ambition and seek alliances with insider organisations and coalitions such as WWF or We Mean Business.

7. Actor type (actor shape): actors are divided into non-state actors and state actors. Non-state actors are subdivided into non-governmental organisations (NGOs, circle); NGO networks (circle with border circles); social movements (triangle); movements of movements (triangle within a triangle), which are alignments of social movements; and individuals (star). State actors (rectangle) are subdivided into the UK government (department, select committee, all-party parliamentary group, and statutory body) devolved nation, region/county and district, and intergovernmental organisations. It is important to note that, following Costoya [28], our definition of "NGO" is more expansive and literal than is customary. We use NGO here as a label for all non-state actors that are organisations as opposed to social movements (Table 3, column 7).

8. Actor sector: we categorised actors according to the GHG mitigation sector in which they are engaged, broadly following the UK Committee on Climate Change's "outcome indicators"-all sectors, agriculture, buildings, GHG removal, f-gases, industry, land use, forestry, energy, transport, and waste [29,59]. For the NGO sector, we assigned NGOs to one of fourteen sectors that best describes their primary source of income, membership, or support-the arts, business/professions, citizens, community/city, environment, finance, health, law/litigation, media, political parties, religions, research (academic), research (think tank), and trade unions [27,60,61];

9. Modus operandi: actors employ various methods, tactics, and performances to further their aims [62]. The inclusion of modus operandi creates a richer description of each actor and may reveal patterns, strategic links, and informal alignments of actors adopting similar tactics. One example is the small but growing set of professional associations that have recently made "declarations of climate emergency", some of which include commitments to avoid projects that would increase the burning of fossil fuels, including airport expansion schemes. The list of methods is presented in Table 3, column 9;

10. Political discourse: in addition to policy discourses (item 4), this typology categorises political discourses used to motivate and persuade the public and other actors to support their cause, shaping "how we see and imagine problems and solutions, and how we come to define, know, and frame futures" [30] (p. 21). Political discourses are divided into grand narratives, counter-narratives, and motivational frames. Grand narratives are defined as compelling, unifying stories for rapid transition to a more sustainable future, based on themes such as restoration, redemption, and emergence [63-67]; counter-narratives are discourses designed to delay decarbonisation and concerted action on climate change. We reproduced Lamb et al.'s [68] list of twelve delay discourses, grouped into four overall delay strategies. Motivational Frames can be used by any actor to encourage or discourage action on climate change. The motivating efficacy of political discourses depends on many factors, including recipients' values, social identity [69,70], and the perceived trustworthiness of messengers [71]. Political messaging is therefore often tailored to appeal to specific contexts and audiences.

Table 2. Actor scales (y-axis).

\begin{tabular}{ccccc}
\hline Scale & & & \\
\hline 5 & & \multicolumn{2}{c}{ International } \\
\hline 4 & England & Scotland & Wales & Northern Ireland \\
\hline 3 & Region/County & Council Area & Principle Area & County \\
\hline 2 & District & & & District \\
\hline 1 & & & & \\
\hline
\end{tabular}


Table 3. Typology of actors in UK greenhouse gas mitigation politics and policy.
1. Actor Name (label):
2. Scale (y-axis): District, Region/County, Devolved Nation, UK, International
3. Net-Zero Ambition (x-axis): 2025-2030, 2031-2035, 2036-2040, 2041-2045, 2046-2055, 2051-2055, >2055
4. Policy Discourse (colour): Revolution, Participation, Limits, Growth, Delay
5. Relative Influence (size):
6. Policy Insider/Outsider:

\begin{tabular}{|c|c|c|c|c|}
\hline 7. Actor $\mathrm{Ty}$ & 8. Actor Sector & 9. Modus Operandi & 10. Political Discourse & \\
\hline $\begin{array}{l}\text { Non-State Actors: } \\
\text { NGOs (circle) } \\
\text { NGO Networks } \\
\text { (circle + circle border) } \\
\text { Social Movements } \\
\text { (triangle) } \\
\text { Movement of } \\
\text { Movements } \\
\text { (double triangle) } \\
\text { Individuals (star) } \\
\text { State Actors (all } \\
\text { rectangles) } \\
\text { UK Government } \\
\text { - Departments } \\
\text { - Select } \\
\text { Committees } \\
\text { All Party } \\
\quad \text { Parliamentary } \\
\quad \text { Groups (APPGs) } \\
\text { Statutory Bodies } \\
\text { Devolved Nations } \\
\text { Regions/Counties } \\
\text { Districts } \\
\text { Intergovernmental } \\
\text { Organisations (IGOs) }\end{array}$ & $\begin{array}{l}\text { NGO Sectors: } \\
\text { The Arts } \\
\text { Business/professions } \\
\text { Citizens } \\
\text { Community/city } \\
\text { Environment } \\
\text { Finance } \\
\text { Health } \\
\text { Law/litigation } \\
\text { Media } \\
\text { Political parties } \\
\text { Religions } \\
\text { Research/academy } \\
\text { Research/think } \\
\text { tank } \\
\text { Trade unions }\end{array}$ & $\begin{array}{l}\text { Traditional Methods: } \\
\text { Art/performance } \\
\text { Boycott } \\
\text { Civil disobedience } \\
\text { Demonstrate/march } \\
\text { Divest/reinvest } \\
\text { Donate/subscribe } \\
\text { Lobby } \\
\text { Occupy space } \\
\text { Petition } \\
\text { Policy advocacy } \\
\text { Public meeting } \\
\text { Publish } \\
\text { Strike } \\
\text { Education/training } \\
\text { Disinformation } \\
\\
\text { Recent Methods } \\
\text { Deliberative } \\
\text { democracy } \\
\text { Digital media } \\
\text { campaign } \\
\text { Internet call to action } \\
\text { Litigation } \\
\text { Prefigurative politics } \\
\text { Strike from school }\end{array}$ & 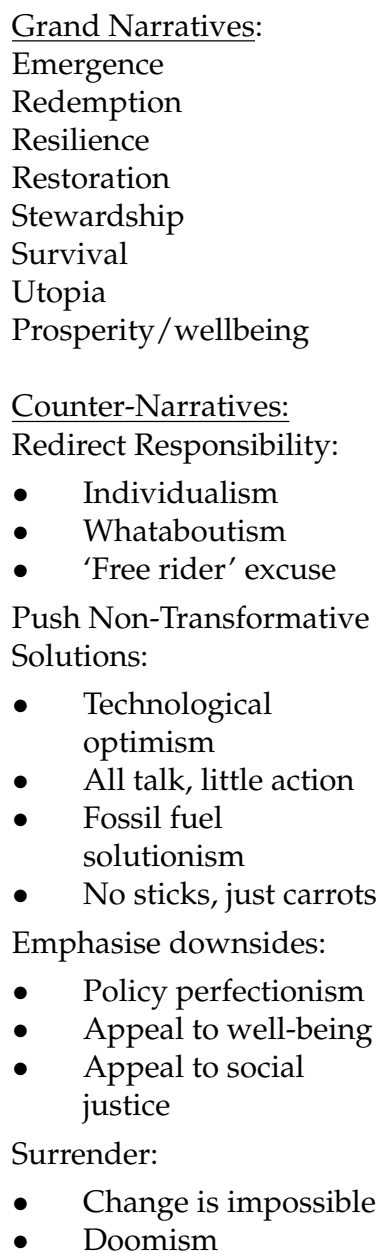 & $\begin{array}{l}\text { Motivational Frames } \\
\text { Ego +: self- } \\
\text { enhancement/co-benefits, } \\
\text { legacy, reputation [72-74] } \\
\text { Ego -: negative emotions, } \\
\text { e.g., fear, shame, guilt, } \\
\text { outrage, [75] } \\
\text { Conserving: conserving } \\
\text { goods of natural/capital } \\
\text { value: love of land, home, } \\
\text { heritage [76-78] } \\
\text { Altruist: concern for the } \\
\text { welfare of others [72] } \\
\text { Collectivist: concern for the } \\
\text { welfare of a specific group; } \\
\text { loyalty; solidarity [72] } \\
\text { Principlist: ethics of justice, } \\
\text { fairness, humanity, rights, } \\
\text { freedom, the greatest good } \\
\text { [72,77,79,80] } \\
\text { Normative: human } \\
\text { tendency to imitate and } \\
\text { conform to perceived social } \\
\text { norms [81,82] } \\
\text { Self-transcendent: a } \\
\text { trans-generational cause } \\
\text { that extends beyond one's } \\
\text { own limited existence } \\
\text { [77,79,83,84] }\end{array}$ \\
\hline
\end{tabular}

\subsection{Design Method for the State Actor Organigram and Non-State Actor Map}

The suitability of various mapping methods was investigated. Reviewed software included Gephi (used primarily for network analysis), Tableau (used broadly in graphic design), draw.io (used primarily for flow and process diagrams), and Adobe Illustrator (used broadly in graphic design). Since the main purpose of the larger research programme for which this study is a part focuses on decarbonisation targets, policy discourses, relative influence, and scale of operations, Apple Keynote—a package capable of arranging differently sized, coloured, and labelled shapes along XY axes-was considered suitable. The non-state actor map design was influenced by Boehnert [27] and Barbrook-Johnson [19]. The state actor organigram design was influenced by Willis et al. [39] and Turnberry et al. [38].

The state actor organigram (Figure 7) and the non-state actor map (Figure 8) illustrate two ways of applying the typology. State actors are shown as grey rectangles, from intergovernmental organisations down to UK local authorities. Space permits only the numbers of subnational authorities and illustrates the complexity of this type of mapping exercise. The non-state actor map utilised the following elements of the typology: name, scale, net-zero ambition, policy discourse, relative influence, actor type, and the 14 NGO sectors. The map 
therefore serves to highlight the following features of UK NGOs, social movements, and individuals engaged in climate mitigation:

- "net-zero ambition" for the UK as a whole: along the x-axis in columns separated by dotted lines. Actors in the same column (e.g., 2046-2055) share the same range of UK net-zero ambition, regardless of their location from the left to the right of the column; the left-right sortition of actors within the same row and column reflects only their influence relative to other actors in that row and column, as explained in "relative influence" below;

- "policy discourse", as indicated by the actor's colour (Figure 8 legend). Note that, for the "participation" discourse (yellow), several actors may collectively occupy the same object, stretched across several columns of net-zero ambition. This illustrates the priority of this discourse to encourage public participation and deliberative decisionmaking rather than to rely on top-down targets and solutions;

- "relative influence". Actors within the same sector (single row) were sized according to a standardised average of relative quantitative measures of "relative influence" (from 1-100), together with a degree of judgement and external expert review. The layout of actors within each sector (single row) of the map follows a two-stage sorting process. The first stage sorts all actors within each sector by relative influence from left (low influence) to right (high influence); a second stage then re-positions each actor in the row according to their range of net-zero ambition (e.g., 2025-2030, 2031-2035, etc). Actor size remains unchanged, but the left-right sortition is now only maintained within each column of net-zero ambition. It is therefore possible to have a larger-sized (highly influential) actor placed to the left of a smaller one, but only if that larger actor occupies an earlier, more ambitious range of net-zero ambition.

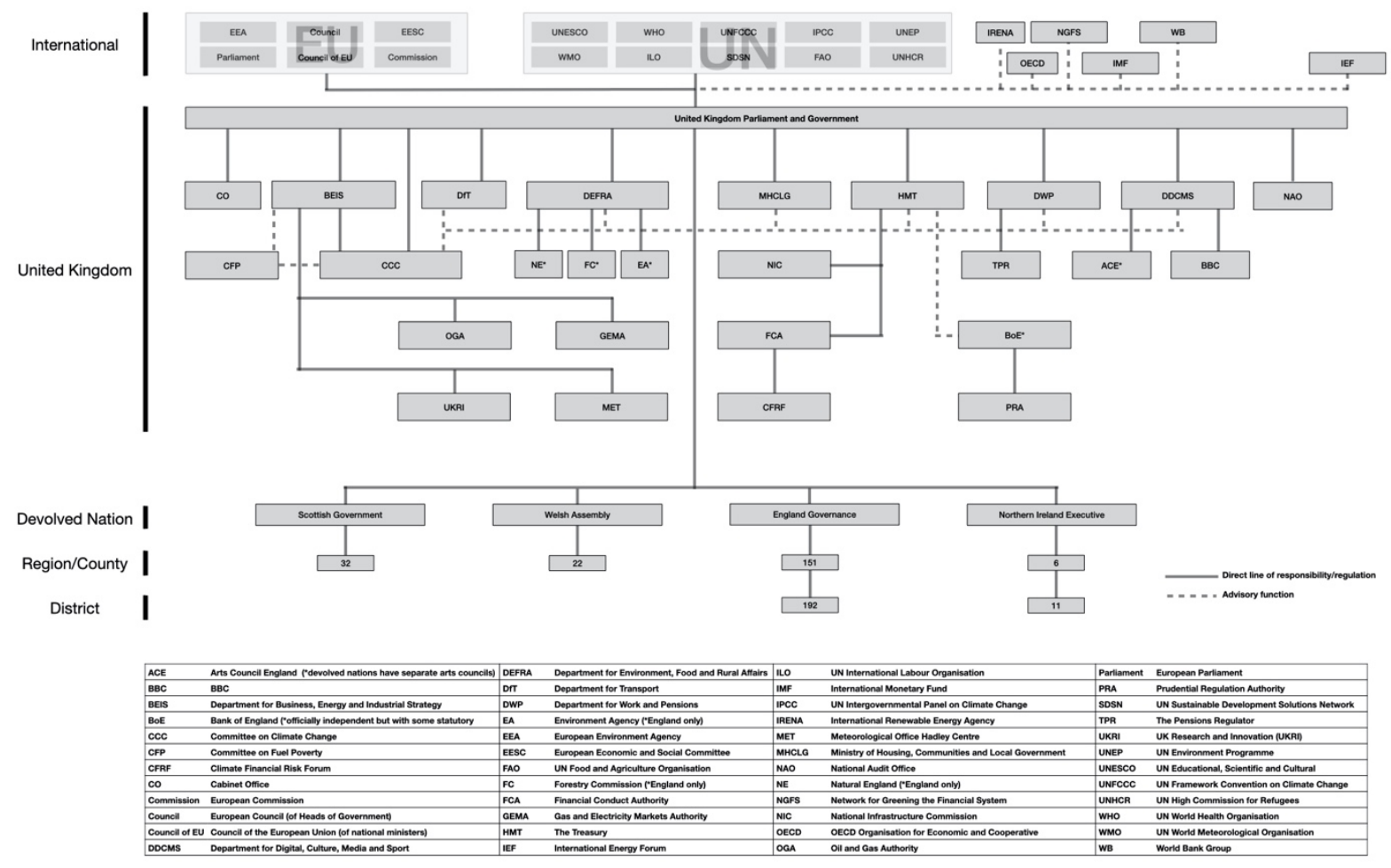

Figure 7. Organigram of state actors influencing UK climate change mitigation policy. 



Figure 8. Map of non-state actors influencing UK climate change mitigation politics and policy. 
It is worth noting that some companies (e.g., IKEA), civil society institutions (e.g., the Church of England), cities, and local authorities (e.g., Leeds, Oxford, Brighton and Hove, Surrey, Edinburgh, and Belfast, with the help of organisations like the Place-Based Climate Action Network (PCAN), C40 Cities, and UK100) are developing more ambitious climate action plans than the UK government as a whole. This may help to accelerate the decarbonisation transition of the UK government in the future. However, this level of complexity was not considered helpful in our example illustrations.

\section{Results}

The typology presented in Table 3 proposes ten descriptors for actors involved in climate mitigation politics and policy in the UK, as detailed in the Methodology section above. The typology represents an integration of knowledge from the fields of geography, sociology, psychology, organisation management, and political science.

Notes in parentheses indicate how descriptors have been subsequently used in the map of non-state actors (Figure 8), which situates actors according to their net zero target for the UK as a whole. Depending on the researcher's focus, different policy goals could be substituted for "net zero ambition" and categorised in item 3. Similarly, alternative policy discourse types could be substituted in item 4, according to a different qualitative analysis. The organigram of state actors (Figure 7) uses only items 1 (label), 2 (scale), and 7 (state actor type) of the typology.

Alternative uses of the typology could focus, for example, on mapping the methods (item 9) or political discourses (item 10) used by actors to influence public opinion or policy decision-making on GHG removal technology or transport policy (item 8). The success of social movements, political campaigns, policy coalitions, and other interventions all depend to some extent on how these various methods and discourses are used and by whom. Successful outcomes might depend on alignments of discourse or political/policy goals among a broad cross section of influential actors or on the use of methods and discourses that appeal to particular audiences and decision-makers.

Figure 7 illustrates one way of mapping state actors that influence GHG mitigation in the UK. It uses items 1 (actor name), 2 (geographical scale), and 7 (actor type-state actors) of the typology. Within typology item 7 (actor type-state actors), government departments and statutory bodies but not select committees or all-party parliamentary groups (APPGs) are included in the organigram. Actors are shown as grey rectangles, from intergovernmental organisations down to local district authorities, connected either by a solid line (indicating a direct line of responsibility/regulation) or by a dotted line (advisory function). Figure 7 largely captures actors at the UK scale, with an overview of international and sub-UK actors. Space permits only the numbers of subnational authorities to illustrate the potential complexity of this type of mapping exercise. Government departments and statutory bodies responsible only for climate-related adaptation are not included.

Figure 8 illustrates one method for mapping the UK net-zero carbon policy targets and discourses of 190 non-state actor organisations and 25 individuals, using items 1-5, 7 , and 8 of the typology (Table 3). Referring to typology item 7 (actor type), 5 types of non-state actors-NGOs, NGO networks, social movements, movements of movements, and individuals - are identified in Figure 8 according to their shape (see Figure 8 legend). Only one actor is identified as a "movement of movements": Global Climate Strike (GCS) (row: international social movement; column: 2031-2035).

Each actor's fill-colour signifies one of 5 policy discourses (see Figure 8 legend)revolution, participation, limits, growth and delay. Each actor's size corresponds to its influence within its own sector (single row), as explained in the Methodology section. As in the Figure 7 organigram, Figure 8 largely emphasizes the UK-scale ecosystem (including 14 sectors of UK NGOs (one row per sector), plus one row each for social movements and individuals. The rows at the top of Figure 8 are an overview of international actors in which all international NGOs are provided one row, plus one row each for social movements and individuals. 
Each column refers to a 5-year net zero carbon target range for the UK as a whole, from 2025-2030 to $>2055$. All actors within each column share the same target but are positioned from left to right within each column by size (relative influence).

Subnational actors are not included due to space limitations and because, by definition, they focus on subnational policy agendas. However, the subnational rows are included to illustrate the potential for different geographical scales to be expanded or contracted depending on the research focus.

\section{Discussion}

The clearest observation in the map of non-state actors (Figure 8 ) is the strength of the group of actors aligning with the UK government's official 2050 net-zero target in terms of number of organisations, breadth of cross-sectoral support, collective influence, coherence of policy discourse in favour of "growth" (blue)—an economic growth and jobs-led transition to a low-carbon economy. This is a technocentric, "eco-modernisation" approach $[21,85]$ which views GDP growth as necessary for, or at least compatible with, the country's global climate responsibilities. A detailed plan has yet to be put forward by the government explaining how a UK transition to net-zero carbon by 2050-which would require a whole-systems approach, cross-sectoral coordination, and wide public support-can be achieved at all, let alone achieved within sustainable limits and without relying on untried or hypothetical carbon removal technologies.

The blue "growth" policy discourse disappears as one proceeds leftwards, as it becomes less possible to reconcile a faster decarbonisation transition-requiring increasingly more radical and costly economic restructuring, infrastructure projects, retraining and redistribution - with a commitment to GDP growth.

There is a significantly smaller, less-influential alignment of more radical actors with a net-zero ambition of 2030-2045. This includes social movements, organisations and networks and largely maps onto a post-growth "limits" discourse (green)—one that prioritises the Earth's biophysical capacities and social foundations necessary for a sustainable future [16-18,86]. A plan for implementing this policy discourse is also unclear, not least in terms of public understanding and political support.

Figure 8 suggests that particular tensions may be predicted to exist within and between organisations where a more radical (pre-2045) net-zero ambition is combined with a "growth" policy discourse. One illustration of this is the positioning of the Labour Party, the Trade Union Congress (TUC) and the Unite union, and their apparent divergence from other unions such as Unison, the GMB, the National Farmers Union (NFU), and the NASUWT (see Figure 8 and legend). This analysis is supported by evidence gathered from interviews: despite efforts to display unity before the 2019 UK general election, there is an ongoing debate within and between unions as they attempt to reconcile their traditional support for economic growth alongside a more recent commitment to rapid decarbonisation.

Conversely, tensions may also be expected to exist within and between organisations where a less ambitious net-zero ambition is combined with a "limits" policy discourse. The clearest examples shown in Figure 8 are Oxfam and the Catholic Agency for Overseas Development (CAfOD). Both are well-established charities in the humanitarian and development aid sector with strong ethical profiles. A "limits" policy discourse that prioritises ecosystem health and human wellbeing over economic growth is therefore consistent with their aims. However, they are also charities seeking broad appeal for continued funding, which may affect their willingness to adopt a more radical policy position. The fact that their work is focused on foreign projects may also lessen their focus on UK policy. However, since all emissions have global consequences, tensions may exist within these organisations to press for more ambitious UK targets on behalf of developing countries that may expect more severe climate impacts.

Figure 8 also highlights other large, public-facing charities such as WWF, for which the policy discourse is labelled as "growth". WWF is situated at the boundary between 
a predominantly "growth" discourse and a predominantly "limits" discourse. This may signal internal tensions. In November 2018, WWF launched its "Keeping it Cool" report, which advocated a 2045 net-zero target for the UK [87]. WWF also maintains a strong commitment to the Intergovernmental Panel on Climate Change's (IPCC) $+1.5^{\circ} \mathrm{C}$ global overheating threshold for respecting planetary boundaries [2], but remains silent on questions of constraints on consumption and economic growth. Interviewees for this research study reported that staff at many of the large environmental NGOs face conflicts concerning their professional roles, their relationships with a wide range of corporate stakeholders, their "insider" status within the policy process of governmental and intergovernmental institutions, and their personal views, which might lead them to actively support more radical groups such as Extinction Rebellion outside their work role.

Another example of possible tensions at this blue-green intersection is the case of Christian Aid, another charity for which the "limits" (green) discourse emphasises ethical, social and ecological principles, but which is aligned in terms of net-zero ambition with WWF (blue). Both Christian Aid and WWF took part in The Climate Coalition's (also blue) "The Time is Now" campaign. If it were possible to research in detail within organisations, it might be possible to produce intra-organisational maps that illustrate differently shaped or coloured coalitions and subcultures, possibly sized according to levels of seniority/influence.

For certain groups, such as the Centre for the Understanding of Sustainable Prosperity (CUSP), the purpose of which is to cultivate a deeper, wider discussion on societal and economic transformation, the tensions produced by a wide diversity of views and ambitions among members may be a design feature. For others, for example, local authority stakeholders struggling to forge consensus for their climate policy action plan, such a diversity may be a disadvantage. The mapping exercise described here could be a helpful tool for this purpose.

A number of non-state actors, the UK government and many local authorities support the principle of deliberative democracy and public participation in the transition to a low-carbon economy. However, for the purposes of this study, actors coloured in yellow for their "participation" policy discourse represent those whose primary focus is on creative or deliberative methods and do not therefore specify net-zero targets. The yellow circles are therefore stretched across net-zero target ranges, highlighting their potential to engage and mobilise diverse constituencies.

The group of organisations seeking to delay (purple) decarbonisation beyond 2055 are well represented by media organisations, associations representing fossil fuel and related interests, and right-wing think tanks. This group tends to dismiss or sow doubt on climate science; distrusts government-led interventions; and champions a low-tax, libertarian market economy and the pursuit of private wealth $[37,88]$. However, relative to some other G20 countries such as the USA, Russia, or Brazil, the influence of this group on the UK political and policy process is weak.

Figure 8 enables some hypotheses to be posed about strategic coalition-building in the UK, as underpinned by theoretical constructs such as "strategic action fields" [25]. One hypothesis could state that, in order to further their policy objectives, smaller actors with more radical net-zero ambitions and policy discourses may attempt to forge closer alignment, coalitions or policy visions with larger actors. For example, the New Economics Foundation (NEF, research think-tank in the 2025-2030 column) might seek to persuade the Unite union to adopt a more ambitious decarbonisation agenda; alternatively, WWF might look to co-opt some influential "growth" organisations in the 2045-2055 column and to persuade them to bring their target forward to match WWF's own 2045 target. Another hypothesis could propose that climate actors tend to adjust their policy positions to exploit new opportunities for support (either political or financial) within their ethical boundaries: for example, WWF might bring forward its own target to 2040 or earlier: not so radical a shift to alienate its existing supporters, but enough to attract a new cohort of grassroots supporters who might feel that a 2030 net-zero target is unrealistic. Similar shifts by other 
actors may generate a new "strategic action field" or coalition based on a compromise "green new deal" with a net-zero target of 2040 or earlier.

However, as indicated by the lack of influential actors (or indeed any actors) in many of the NGO sector rows in the pre-2045 columns in Figure 8, radical coalitions for a more rapid transition face major challenges. Without the support of actors in government, business or finance, a coalition for rapid change needs to be civil society- and social movement-led [89]. A sufficiently broad, motivated coalition of people and organisations would need to mobilise around a unified goal, eventually reaching a critical "mass" and "momentum" that demonstrates the political mandate for change [44,90-92] A crucial element to success, which applies equally to social movements such as Extinction Rebellion [93], to participatory processes such as climate assemblies, and to NGO campaigns, lies in the ability of these actors to develop enduring networks of support [94-97]. Urgenda (Figure 8, column 2036-2040, row International NGO) is a good example. This Dutch foundation has built upon its successful climate lawsuit against the Dutch government by developing a network of hundreds of civil society groups.

At the same time, the dominant growth/net-zero by 2050 coalition can be expected to respond to any risk of losing support to a competing group. One potential response predicted by social movement theory is assimilation and appropriation, whereby the incumbent coalition adopts some of the language and concepts of a challenger, but without fundamentally changing policy, in order to neutralise the threat. Arguably, we see this happening with variations of "green deal", "new deal", and "just transition" being included in influential EU and UK government policy proposals and business fora.

There may be multiple avenues for elaboration and improvement of the mapping methods. With regard to the organigram, state actors could be differentiated by type and by degree of influence and could include the advisory ecosystem of statutory committees, All Party Parliamentary Groups (APPGs), and other sub-departmental entities.

With regard to non-state actors, some researchers may wish to differentiate actors solely engaged in policy development from those engaged in political action. It might also be possible to devise a method to compare the relative influence of non-state actors inter-sectorally as well as intra-sectorally. This mapping exercise represents the formal alliances and associations of non-state actors as a single datapoint rather than mapping their individual memberships into linked and overlapping networks. A more sophisticated visualisation may be capable of offering both. Other metrics for relative influence might also be worth consideration: for example, we calculated the relative influence of political parties according to the respective number of MPs; another option would be to calculate influence by proportional representation.

The labelling of policy discourses is invariably subject to interpretation, data selection, and context. Our "growth" designations may be particularly prone to challenge since they cover a wide range of actors including trade unions, faith groups, environmental NGOs, and financial investors. As already acknowledged with respect to "participation", policy discourse labels are not necessarily mutually exclusive. However, we argue that a reasonably robust and mutually exclusive distinction does exist between "growth" and "delay" actors, on one hand, and "limits" and "revolution" actors on the other hand-a distinction that supports the theory of "core beliefs" in the Advocacy Coalition Framework: the common feature of "growth" and "delay" actors despite their otherwise significant differences is their core belief in economic growth, whether for the purpose of providing jobs, profits, or a technocentric transition. The core belief of "limits" and "revolution" actors, despite their different strategies for change, is that the natural limits of the Earth's ecosystems and human wellbeing come first.

Finally, a longitudinal study mapping the dynamics of actors, coalitions, and alignments over time would be a valuable contribution. The political and policy positions of climate actors are particularly dynamic at present due to many factors, including the coronavirus pandemic; the UK's exit from the European Union; growing public awareness of the climate crisis; new scientific findings; and ongoing "teachable events", such as extreme 
weather and biodiversity losses. In response, actors are mobilising new coalitions and discourse alignments, the more progressive of which seek to accelerate the transition to a low-carbon economy, to take what life under "lockdown" taught us about "what we really value", and to "build back better".

Defining how and what we wish to "build" are the key points of contention. The more radical "limits" actors are mindful of opportunities lost in the aftermath of the 2007/8 financial crisis, when the original "green new deal" recovery plans failed to gain traction in the UK policy agenda [98]. Certain organisations identified in Figure 8, for example, the Wellbeing Economy Alliance (WeAll), may be particularly well-placed to rapidly expand their policy influence and network-building in the short to medium term. However, WeAll and other actors proposing alternatives to growth face formidable obstacles in advancing their theories of change. The "growth" paradigm is a core belief of the most influential actors.

For instance, IPPR's Environmental Justice Commission and the \#BuildBackBetter coalition of civil society organisations have both recruited an impressively broad range of political actors seeking a "fair and green economy" [99] (p. 2). These and other new multi-stakeholder initiatives are negotiating towards shared meanings of a more equal, vibrant, and resilient post-pandemic economy. However, "the space of political imagination has already been defined and the boundaries set" by the imperative for growth [100] (p. 21). The essential truths of the climate and ecological crisis—that "physics doesn't negotiate" [101]; that sufficient absolute decoupling of GDP growth from material consumption and GHG emissions, which is the definition of genuinely "green growth", lacks any empirical evidence [14,102]; and that limits to growth will inevitably be imposed one way or another-await serious discussion in policy circles.

\section{Conclusions}

The proposed typology offers a systematic way to categorise climate actors and their key descriptors and could make a contribution to mapping the configurations, dynamics, and tensions in any climate politics landscape. The state actor organigram and non-state actor map present two ways (among many others) to configure elements of this typology to construct a useful overview of the ecosystem of actors. The map may be used in other ways to analyse any combination of the following:

- $\quad$ actors and scales, from the international to local levels or within a single organisation;

- actors within any mitigation sector or a combination of sectors (e.g., buildings or transport);

- actors within any NGO sector or a combination of NGO sectors (e.g., finance or political parties);

- policy targets (e.g., actors' own individual targets, industry-wide targets, or regional targets); and

- $\quad$ policy discourses, political discourses, or advocacy methods.

The $x$-axis, $y$-axis, object shapes, object borders, and object colours could be reconfigured to illustrate different elements of the typology or to highlight interesting clusters and anomalies, for example, the divergence of trade unions. These methods could be replicated for any country and useful cross-country comparisons could be made.

Author Contributions: Conceptualization, S.R.S. and I.C.; methodology, S.R.S. and I.C.; software, S.R.S.; formal analysis, S.R.S. and I.C.; investigation, S.R.S.; resources, S.R.S.; data curation, S.R.S.; writing-original draft preparation, S.R.S.; writing—review and editing, S.R.S. and I.C.; visualization, S.R.S. and I.C.; supervision, I.C. All authors have read and agreed to the published version of the manuscript.

Funding: This research received no external funding.

Institutional Review Board Statement: This study was conducted according to the guidelines of the Declaration of Helsinki, and approved by the Ethics Committee of the University of Surrey (UEC 2019089 FEPS, approved 04 November 2019). 
Informed Consent Statement: Informed consent was obtained from all subjects involved in the study.

Acknowledgments: Draft versions of the state actor organigram and non-state actor map were submitted to a panel of sixteen experts for informal review. Ten of the sixteen responded with comments, eight of whom have consented to be identified. This study is grateful to all respondents, including Tanisha Beebee, Senior Policy Advisor, Energy and Climate Change, Confederation of British Industry (CBI); Laura Grant, Specialist, Environmental Audit Committee Secretariat, House of Commons; Duncan Green, Professor in Practice and Senior Strategic Advisor at Oxfam GB; Becky Mawhood, Specialist, Business, Energy and Industrial Strategy Committee Secretariat, House of Commons; Brendan Moore, Tyndall Centre and Centre for Climate Change and Social Transformations, University of East Anglia; Lucy Stone, Our Common Climate; Katherine Trebeck, Advocacy and Influencing Lead, Wellbeing Economy Alliance (WeAll); and Rebecca Willis, Professor in Practice, University of Lancaster.

Conflicts of Interest: The authors declare no conflict of interest.

\section{References}

1. IPBES. Summary for Policymakers of the Global Assessment Report on Biodiversity and Ecosystem Services of the Intergovernmental Science-Policy Platform on Biodiversity and Ecosystem Services; IPBES Secretariat: Bonn, Germany, 2019. Available online: https: / / www.biologicaldiversity.org/programs/biodiversity/pdfs/Summary-for-Policymakers-IPBES-Global-Assessment.pdf (accessed on 12 July 2020).

2. IPCC. Summary for Policymakers. In Global Warming of $1.5^{\circ} \mathrm{C}$ Special Report; Intergovernmental Panel on Climate Change; World Meteorological Organisation: Geneva, Switzerland, 2018. Available online: https://www.ipcc.ch/sr15/ (accessed on 8 January 2020).

3. UNFCCC. The Paris Agreement. United Nations Framework Convention on Climate Change. In Proceedings of the 21st Paris Climate Change Conference, Paris, France, 12 December 2015. Available online: https://unfccc.int/documents/9064 (accessed on 6 April 2016).

4. Figueres, C.; Rivett-Carnac, T. The Future We Choose: Surviving the Climate Crisis; Manila Press: London, UK, 2020.

5. Climate Transparency, 2018. Brown to Green: The G20 Transition to a Low-Carbon Economy. Available online: www.climatetransparency.org/g20-climate-performance/g20report2018 (accessed on 20 September 2019).

6. Overland, I.; Sovacool, B.K. The Misallocation of Climate Research Funding. Energy Res. Soc. Sci. 2020, 62, 101349. [CrossRef]

7. Gillion, D.Q. The Loud Minority: Why Protests Matter in American Democracy; Princeton University Press: Oxford, UK, 2020.

8. Köhler, J.; Geels, F.W.; Kern, F.; Markard, J.; Onsongo, E.; Wieczorek, A.; Alkemade, F.; Avelino, F.; Bergek, A.; Boons, F.; et al. An Agenda for Sustainability Transitions Research: State of the Art and Future Directions. 2019. Available online: https: //transitionsnetwork.org/wp-content/uploads/2016/09/STRN_Research_Agenda_2019c-2.pdf (accessed on 20 April 2019).

9. Roberts, C.; Geels, F.W.; Lockwood, M.; Newell, P.; Schmitz, H.; Turnheim, B.; Jordan, A. The Politics of Accelerating Low-Carbon Transitions: Towards a New Research Agenda. Energy Res. Soc. Sci. 2018, 44, 304-311. [CrossRef]

10. Hess, D.J. Energy Democracy and Social Movements: A Multi-Coalition Perspective on the Politics of Sustainability Transitions. Energy Res. Soc. Sci. 2018, 40, 177-189. [CrossRef]

11. Anderson, K.; Broderick, J.F.; Stoddard, I. A factor of two: How the mitigation plans of climate progressive nations fall far short of Paris-compliant pathways. Clim. Policy 2020, 20, 1290-1304. [CrossRef]

12. Jackson, T. Zero Carbon Sooner-The Case for an Early Zero Carbon Target for the UK; CUSP Working Paper No. 18; University of Surrey: Guildford, UK, 2019. Available online: https://www.cusp.ac.uk/wp-content/uploads/WP18-Zero-carbon-sooner.pdf/ (accessed on 3 October 2019).

13. OECD. Beyond Growth: Towards a New Economic Approach, New Approaches to Economic Challenges; OECD Publishing: Paris, France, 2020. [CrossRef]

14. Hickel, J.; Kallis, G. Is Green Growth Possible? New Polit. Econ. 2020, 25, 469-486. [CrossRef]

15. Hausknost, D.; Hammond, M. Beyond the Environmental State? The political prospects of a sustainability transformation. Environ. Polit. 2020, 29, 1-16. [CrossRef]

16. Trebeck, K.; Williams, J. The Economics of Arrival: Ideas for a Grown-Up Economy; Policy Press: Bristol, UK, 2019.

17. Jackson, T. Prosperity without Growth, 2nd ed.; Routledge: Abingdon, UK, 2017.

18. Raworth, K. Doughnut Economics; Penguin: London, UK, 2017.

19. Barbrook-Johnson, P. Innovative Partnerships: A Review of Innovative Public-Private Partnerships in Food-Energy-WaterEnvironment Domains in the UK. CECAN Report. 2019. Available online: www.cecan.ac.uk/resources (accessed on 12 July 2020 ).

20. Hajer, M.A.; Versteeg, W. Voices of Vulnerability: The Reconfiguration of Policy Discourses. In The Oxford Handbook of Climate Change and Society; Drysek, J.S., Norgaard, R.B., Schlosberg, D., Eds.; Oxford University Press: Oxford, UK, 2013 ; pp. 82-95.

21. Hajer, M.A. The Politics of Environmental Discourse: Ecological Modernisation and the Policy Process. Oxford Scholarship Online. 1997. Available online: https:/ / www.oxfordscholarship.com/view/10.1093/019829333X.001.0001/acprof-9780198293330 (accessed on 13 March 2020).

22. Entman, R. Framing: Toward clarification of a fractured paradigm. J. Commun. 1993, 43, 51-58. [CrossRef] 
23. Hess, D.J. Coalitions, framing, and the politics of energy transitions: Local democracy and community choice in California. Energy Res. Soc. Sci. 2019, 50, 38-50. [CrossRef]

24. Sabatier, P.A. The advocacy Coalition Framework: Revisions and relevance for Europe. J. Eur. Public Policy 1998, 5, 98-130. [CrossRef]

25. Fligstein, N.; McAdam, D. A Theory of Fields; Oxford University Press: New York, NY, USA, 2012.

26. Williams, L.; Sovacool, B.K. Energy Democracy, Dissent and Discourse in the Party Politics of Shale Gas in the United Kingdom. Environ. Polit. 2020. [CrossRef]

27. Boehnert, J. Mapping Climate Communication. Poster Summary Report. 2014. Available online: https://www.academia.edu/20 21767/Mapping_Climate_Communication_Poster_Summary_Report (accessed on 19 April 2020).

28. Costoya, M.M. Toward a Typology of Civil. Society Actors: The Case of the Movement to Change International Trade Rules and Barriers; Civil. Society and Social Movements Programme Paper Number 30; United Nations Research Institute for Social Development: Geneva, Switzerland, 2007. Available online: http://www.unrisd.org/80256B3C005BCCF9/httpNetITFramePDF?ReadForm\& parentunid=0451352E376C1031C12573A60044CE42\&parentdoctype=paper \&netitpath=80256B3C005BCCF9 / (httpAuxPages) /0451352E376C1031C12 (accessed on 24 June 2018).

29. Committee on Climate Change (CCC). Reducing UK Emissions. 2018 Progress Report to Parliament. 2018. Available online: https:/ / www.theccc.org.uk/publication/reducing-uk-emissions-2018-progress-report-to-parliament/ (accessed on 8 July 2020).

30. Scoones, I.; Newell, P.; Leach, M. The Politics of Green Transformations. In The Politics of Green Transformations; Scoones, I., Leach, M., Newell, P., Eds.; Routledge: Abingdon, UK, 2015; pp. 1-24.

31. Sovacool, B.J.; Geels, F.W. Further Reflections on the temporality of energy transitions: A response to critics. Energy Res. Soc. Sci. 2016, 22, 232-237. [CrossRef]

32. Oxfam International. How to Analyse Change Processes; Research Guidelines: Oxford, UK, 2019. Available online: https:/ / policypractice.oxfam.org.uk/publications/how-to-analyse-change-processes-620866 (accessed on 20 June 2020).

33. Climate Assembly UK. Advisory Panel. 2020. Available online: https://www.climateassembly.uk/detail/advisorypanel/ (accessed on 8 July 2020).

34. Tarrow, S. Power in Movement: Social Movements and Contentious Politics; Cambridge University Press: New York, NY, USA, 2011.

35. Rao, A.; Sandler, J.; Kelleher, D.; Miller, C. Gender at Work: Theory and Practice in 21st Century Organisations; Routledge: Abingdon, UK, 2016.

36. Raekstad, P.; Gradin, S.S. Prefigurative Politics: Building Tomorrow Today; Polity Press: Cambridge, UK, 2020.

37. Oreskes, N.; Conway, E. Merchants of Doubt: How a Handful of Scientists Obscured the Truth on Issues from Tobacco Smoke to Global Warming; Bloomsbury Press: London, UK, 2010.

38. Turnberry, J.; Haxeltine, A.; Lorenzoni, I.; O’Roprdan, T.; Jones, M. Mapping Actors Involved in Climate Change Policy Networks in the UK. Tyndall Centre for Climate Change Research, 2005. Working Paper 66. Available online: http:/ / citeseerx.ist.psu.edu/ viewdoc/download?doi=10.1.1.111.6089\&rep=rep1\&type=pdf (accessed on 5 January 2020).

39. Willis, R.; Mitchell, C.; Hoggett, R.; Britton, J.; Poulter, H. Enabling the Transformation of the Energy System: Recommendations from IGov; EPSRC/University of Exeter: Exeter, UK, 2019. Available online: https://projects.exeter.ac.uk/igov/enabling-thetransformation-of-the-energy-system/ (accessed on 8 July 2020).

40. Bäckstrand, K.; Kuyper, J.W.; Linnér, B.; Loövbrand, E. Non-state actors in global climate governance: From Copenhagen to Paris and beyond. Environ. Polit. 2017, 26, 561-579. [CrossRef]

41. Bernstein, S.; Hoffman, M. The politics of decarbonization and the catalytic impact of subnational climate experiments. Policy Sci. 2018, 51, 189-211. [CrossRef] [PubMed]

42. Hess, D.J. Sustainability Transitions: A political coalition perspective. Res. Policy 2014, 43, 278-283. [CrossRef]

43. Pacheco-Vega, R.; Murdie, A. When do environmental NGOs work? A test of the conditional effectiveness of environmental advocacy. Environ. Polit. 2020. [CrossRef]

44. Willis, R. Too Hot to Handle? The Democratic Challenge of Climate Change; Bristol University Press: Bristol, UK, 2020.

45. Allan, J.I.; Hadden, J. Exploring the framing power of NGOs in global climate politics. Environ. Polit. 2017, 26, 600-620. [CrossRef]

46. Green, D. How Change Happens; Oxford University Press: Oxford, UK, 2016.

47. Newell, P. Towards a Global Political Economy of Transition: A Comment on the Transitions Research Agenda. Environ. Innov. Soc. Transit. 2020, 34, 344-345. [CrossRef]

48. Bulkeley, H.; Andonova, L.B.; Betsill, M.M.; Compagnon, D.; Hale, T.; Hoffmann, M.J.; Newell, P.; Paterson, M.; VanDeveer, S.D.; Roger, C. Transnational Climate Change Governance; Cambridge University Press: Cambridge, UK, 2014.

49. ONS. All Administrative Names and Codes in the United Kingdom; Office for National Statistics: London, UK, 2020. Available online: https:/ / geoportal.statistics.gov.uk/search?collection=Dataset\&sort=name\&tags=all(NAC_ADM) (accessed on 2 May 2020).

50. Fereday, J.; Muir-Cochrane, E. Demonstrating rigour using thematic analysis: A hybrid approach of inductive and deductive coding and theme development. Int. J. Qual. Methods 2006, 5, 80-92. [CrossRef]

51. Ritchie, J.; Spencer, L.; O'Connor, W. Carrying Out Qualitative Analysis. In Qualitative Research Practice: A Guide for Social Science Students and Researchers; Ritchie, J., Lewis, J., Eds.; Sage Publications: London, UK, 2003; pp. 219-262.

52. Braun, V.; Clarke, V. Using thematic analysis in psychology. Qual. Res. Psychol. 2006, 3, 77-101. [CrossRef]

53. McGann, J.G. 2019 Global Go to Think Tank Index Report; TTCSP Global Go to Think Tank Index Reports; University of Pennsylvania: Philadelphia, PA, USA, 2020. Available online: https:/ / repository.upenn.edu/think_tanks/17 (accessed on 3 May 2020). 
54. Newell, P. Climate for change? Civil society and the politics of global warming. In Global Civil Society Yearbook; Holland, F., Ed.; Sage Publications: London, UK, 2005; pp. 90-119.

55. Piggot, G. The influence of social movements on policies that constrain fossil fuel supply. Clim. Policy 2018, 18, 942-954. [CrossRef]

56. Willis, R. Building the Political Mandate for Climate Action; The Green Alliance: London, UK, 2018. Available online: https: //www.green-alliance.org.uk/resources/Building_a_political_mandate_for_climate_action.pdf (accessed on 12 June 2019).

57. Cohn, N.; Quealy, K. How US Public Opinion Has Moved on Black Lives Matter. The New York Times. 10 June 2020. Available online: https:/ / www.gooriweb.org/news/2000s/2020/nyt10june2020.pdf (accessed on 29 October 2020).

58. Ankel, S. 30 Days That Shook America: Since the Death of George Floyd, the Black Lives Matter Movement Has Already Changed the Country. Business Insider. 24 June 2020. Available online: https:/ / www.businessinsider.com/13-concrete-changes-sparkedby-george-floyd-protests-so-far-2020-6? r=US\&IR=T (accessed on 29 October 2020).

59. Committee on Climate Change (CCC). Net Zero: The UK's Contribution to Stopping Global Warming. 2019. Available online: https: / / www.theccc.org.uk/publication/net-zero-the-uks-contribution-to-stopping-global-warming/ (accessed on 16 January 2020).

60. Climate Assembly UK. 2020. Available online: https:/ / www.climateassembly.uk (accessed on 8 July 2020).

61. Scoones, I.; Leach, M.; Newell, P. (Eds.) The Politics of Green Transformations; Routledge: Abingdon, UK, 2015.

62. Della Porta, D.; Diani, M. Social Movements: An Introduction; Blackwell Publishing: Oxford, UK, 2006.

63. Bushell, S.; Buisson, G.S.; Workman, M.; Colley, T. Strategic Narratives in Climate Change: Towards a Unifying Narrative to Address the Action Gap on Climate Change. Energy Res. Soc. Sci. 2017, 28, 39-49. [CrossRef]

64. Monbiot, G. Out of the Wreckage: A New Politics for an Age of Crisis; Verso: London, UK, 2017.

65. Evans, A. The Myth Gap: What Happens When Evidence and Arguments Aren't Enough; Eden Project Books: London, UK, 2017.

66. Raskin, P. Journey to Earthland: The Great Transition to Planetary Civilisation; The Tellus Institute: Boston, MA, USA, 2016. Available online: http:/ / www.greattransition.org/publication/journey-to-earthland (accessed on 15 March 2017).

67. Klein, N. This Changes Everything; Penguin Books: London, UK, 2014.

68. Lamb, W.F.; Mattioli, G.; Levi, S.; Roberts, J.T.; Capstick, S.; Creutzig, F.; Minx, J.C.; Müller-Hansen, F.; Culhane, T.; Steinberger, J.K. Discourses of climate delay. Glob. Sustain. 2020, 3, 1-5. [CrossRef]

69. Schwartz, S.H. An Overview of the Schwartz Theory of Basic Values. Online Read. Psychol. Cult. 2012. [CrossRef]

70. Kahan, D.M. Fixing the communications failure. Nature 2010, 463, 296-297. [CrossRef] [PubMed]

71. Raven, R.; Kern, F.; Verhees, B.; Smith, A. Niche Construction and Empowerment through Socio-Political Work. A Meta-Analysis of Six Low-Carbon Technology Cases. Environ. Innov. Soc. Transit. 2016, 18, 164-180. [CrossRef]

72. Batson, D.C. Altruism in Humans; Oxford University Press: New York, NY, USA, 2011.

73. Van Vugt, M. Triumph of the Commons. New Sci. 2009, 203, 40-43. [CrossRef]

74. Wade-Benzoni, K.A.; Tost, L.P. The Egoism and Altruism of Intergenerational Behavior. Personal. Soc. Psychol. Rev. 2009, 13, 165-193. [CrossRef]

75. Fehr, E.; Gaechter, S. Cooperation and Punishment in Public Goods Experiments. Am. Econ. Rev. 2000, 90, 980-994. [CrossRef]

76. Leopold, A. A Sand County Almanac; Oxford University Press: Oxford, UK, 1949.

77. Birnbacher, D. What Motivates Us to Care for the Distant Future? In Intergenerational Justice; Gosseries, A., Meyer, L.H., Eds.; Oxford University Press: New York, NY, USA, 2009; pp. 273-300.

78. Scruton, R. Settling Down and Marking Time; Centre for the Understanding of Sustainable Prosperity, University of Surrey: Guildford, UK, 2017. Available online: https:/ /www.cusp.ac.uk/themes/m/rs_m1-2/ (accessed on 18 August 2018).

79. Jonas, H. Imperative of Responsibility: In Search of an Ethic for the Technological Age; University of Chicago Press: Chicago, IL, USA, 1984.

80. Singer, P. The Expanding Circle: Ethics, Evolution and Moral Progress; Princeton University Press: Oxford, UK, 1981.

81. Cialdini, R.; Kallgren, C.; Reno, R. A Focus Theory of Normative Conduct: A theoretical refinement and re-evaluation of the role of norms in human behaviour. Adv. Exp. Soc. Psychol. 1991, 24, 201-234.

82. Turner, J.C. Rediscovering the Social Group: A Self-Categorization Theory; Blackwell Publishing: New York, NY, USA, 1987.

83. Laudato Si'. Encyclical Letter Laudato si' of the Holy Father Francis on Care of Our Common Home; Vatican Press: Vatican City, 2015.

84. Krznaric, R. The Good Ancestor: How to Think Long Term in a Short Term World; W.H. Allen: London, UK, 2020.

85. Christoff, P. Ecological modernisation, ecological modernities. Environ. Polit. 1996, 5, 476-500. [CrossRef]

86. Kallis, G. Limits: Why Malthus Was Wrong and Why Environmentalists Should Care; Stanford University Press: Stanford, CA, USA, 2019.

87. Vivid Economics. Keeping it Cool: How the UK Can End its Contribution to Climate Change. An Analytical Report for WWF. 2018. Available online: https://www.wwf.org.uk/updates/uk-can-lead-way-stopping-climate-change-reaching-net-zero-emissions2045-new-report-reveals (accessed on 8 July 2020).

88. Dunlap, R.E.; McCright, A.M. Challenging Climate Change: The Denial Countermovement. In Climate Change and Society: Sociological Perspectives; Dunlap, R.E., Brulle, R.J., Eds.; Oxford University Press: New York, NY, USA, 2015 ; pp. $393-442$.

89. Dunlap, R.E.; Brulle, R.J. Climate Change and Society: Sociological Perspectives; Oxford University Press: New York, NY, USA, 2015.

90. Smith, S.R.; Christie, I.; Willis, R. Social Tipping Intervention Strategies for Rapid Decarbonisation Need to Consider How Change Happens. Proc. Natl. Acad. Sci. USA 2020, 117, 10629-10630. [CrossRef] [PubMed]

91. Centola, D.; Becker, J.; Brackbill, D.; Baronchelli, A. Experimental Evidence For Tipping Points in Social Convention. Science 2018, 360, 1116-1119. [CrossRef] 
92. Leach, M.; Scoones, I. Mobilising for Green Transformations. In The Politics of Green Transformations; Scoones, I., Leach, M., Newell, P., Eds.; Abingdon: Routledge, UK, 2015; pp. 119-133.

93. Carnegie Endowment for International Peace (CEIP). After Protest: Pathways Beyond Mass Mobilization. 2019. Available online: https:/ / carnegieendowment.org/files/Youngs_AfterProtest_final2.pdf (accessed on 24 October 2020).

94. Centola, D. How Behavior Spreads: The Science of Complex. Contagions; Princeton University Press: Woodstock, UK, 2018.

95. Crutchfield, L.R. How Change Happens: Why Some Social Movements Succeed While Others Don't; John Wiley and Sons: Hoboken, NJ, USA, 2018.

96. Bond, B.; Exley, Z. Rules for Revolutionaries: How Big Organizing Can. Change Everything; Chelsea Green Publishing: White River Junction, VT, USA, 2016.

97. North, P. The Politics of Climate Activism in the UK: A Social Movement Analysis. Environ. Plan A 2011, 43, 1581-1598. [CrossRef]

98. Pettifor, A. The Case for the Green New Deal; Verso: London, UK, 2019.

99. IPPR. Faster, Further, Fairer: Putting People at the Heart of Tackling the Climate and Nature Emergency; Interim Report of the IPPR Environmental Justice Commission; Institute for Public Policy Research: London, UK, 2020. Available online: https: / / www.ippr.org/files/2020-05/faster-further-fairer-ejc-interim-may20.pdf (accessed on 7 July 2020).

100. Cerrato, D.; Ferrando, T. The Financialization of Civil Society Activism: Sustainable Finance, Non-Financial Disclosure and the Shrinking Space for Engagement. Account. Econ. Law A Conviv. 2020. [CrossRef]

101. McKibben, B. Physics Doesn't Negotiate: Notes on the Dangerous Difference between Science and Political Science. Medium. 30 August 2015. Available online: https:/ / medium.com/climate-desk/why-the-earth-is-heating-so-fast-267072ab2b49 (accessed on 8 July 2020).

102. Vadén, T.; Lähde, V.; Majava, A.; Järvensivu, P.; Toivanen, T.; Eronen, J.T. Raising the Bar: On the Type, Size and Timeline of a 'Successful' Decoupling. Environ. Polit. 2020. [CrossRef] 